\title{
Nutritional Evaluation of Fermented by-Products Mixtures in Comparison with Clover Hay and Impact of Its Feeding on Productive Performance of Zaraibi Goats. \\ Mohamed, A. H. ${ }^{1}$; M. M. El-Badawy ${ }^{1}$; M. H. Abo El-Fadel ${ }^{1}$; Amal M. Fayid ${ }^{1}$; M. H. Yacout ${ }^{1}$; K. I. Mohamed ${ }^{1}$ and Ahlam A. EL-Sayed ${ }^{2}$ \\ ${ }^{1}$ Animal Production Research Institute (APRI), Agricultural Research Center, Dokki, Egypt. \\ ${ }^{2}$ Food Technology Research Institute (FTRI), Agricultural Research Center, Dokki, Egypt.
}

\section{ABSTRACT}

This study was conducted to investigate the effect of inclusion fermented field (Potato vines \& rice straw) and food industrial by-product (dried beet pulp \& molasses) mixture (FBM) to be replacement with clover hay in dairy goats does diets and its effect on nutrient digestibility, milk yield, milk composition and some blood parameters. Eighteen lactating Zaraibi goats does, average live body weight of $40.5 \pm 1.5 \mathrm{~kg}$ at the $3^{\text {rd }}$ and $4^{\text {th }}$ parities were divided randomly into three similar groups $(6$ animals each), were used to receive one of 3 experimental diets. The first group was received concentrate feed mixture (CFM) and clover hay $(\mathrm{CH})$ as control diet $(\mathrm{CD})$. Meanwhile, second and third group received CFM and replacement $(\mathrm{CH})$ with (FBM1) which composed of $65 \%$ potatoes vines (PV), $12 \%$ dried beet pulp (DBP), $15 \%$ rice straw (RS) and $8 \%$ molasses as (TD1) group or with (FBM2) which composed of $74 \%$ potatoes vines( PV), $14 \%$ dried beet pulp ( DBP), $7 \%$ rice straw (RS) and $5 \%$ molasses (on dry matter basis) as (TD2) group. The FBM based silage contained on average $41.7 \& 40.5 \%$ dry matter, 12.45 $\& 12.83 \%$ crude protein $(\mathrm{CP})$, and $55.4 \& 52.6 \%$ neutral detergent fiber (NDF), $44.7 \& 40.8 \%$ acid detergent fiber (ADF), Ether extract $2.5 \& 2.2 \%$ and ash content $9.5 \& 10.3 \%$, for (FBM1 \& FBM2), respectively. Results showed that there were no significant differences between two fermented by-products mixtures (FBM1 and FBM2) concerning NH3-N concentration and $\mathrm{pH}$ value. It was also observed that there was an increase in concentration of total volatile fatty acids with mixture (FBM2) compared with (FBM1) mixture. The highest $(\mathrm{P}<0.05)$ digestibility of DM, CP, NDF and ADF was recorded with (TD2). The nutritive values as TDN, DCP and ME (Mcal $/ \mathrm{kg})$ of (TD1 \&TD2) were significantly $(\mathrm{P}<0.05)$ improved compared with control group. While, increasing in TDN for (TD1) was significantly. The highest significantly $(\mathrm{P}<0.05)$ value of milk yield was recorded for group TD2 as compared with control diet (CD), but there were no significant differences between (TD1) and (TD2) group was recorded. Meanwhile, the lowest value of milk yield was recorded with control diet (CD). There were no significant differences between the tested groups concerning milk composition percentages which were almost similar among experimental groups. Also, there were no significant differences between tested groups for some blood parameters (Glucose, AST and ALT). The feeding cost / head /day was decreased by 8.8 and $10.5 \%$ with TD1 and TD2 groups, respectively as compared with control group, leading to an improvement of economic efficiency by 32.7 and $43.6 \%$, with TD1 and TD2 diets, respectively compared with control group. Therefore, the replacement of clover hay with fermented by-products mixtures (FBM1\&FBM2) with dairy goats does diet is highly recommended in the feeding practices of goats.

Keywords: Zaraibi goats, fermented mixed ration, digestibility, milk yield, milk composition and blood parameters .

\section{INTRODUCTION}

Feed is the major input cost in animal production, accounting for $65-70 \%$ of the total production costs and the need for rations based on locally available feedstuffs has shifted nutritionists studies to unconventional feedstuffs for ruminants (Lashkari et al.,2014). Poor nutrition for animals has been identified as the major constraint to animal production across the developing world (FAO, 2008). In Egypt, there is a great mounting pressure on cultivated land and water resources, we have to rely more on by-products from grain and other cash crops for feeding ruminants to produce milk and meat. On the meantime, agricultural by-products (field and food industrial) volume reached around 32 million tons annually (Agricultural Economics-Ministry of Agriculture in Egypt, 2014), more than two third of this amount is left annually without use. The high moisture content of some agricultural by-products field (Potato veins) relative to the nutrient composition makes it costly to transport, difficult to handle and easy to spoil. Also, the sun-drying needs to be suitable for its success atmospheric conditions and its impact on the nutritional value. Fermented By-products Mixture (FBM) is a proper type of feed especially when agricultural by-products with high moisture content are to be included (Li et al., 2003). Nutritionally, Potato veins are a rich source of protein, fiber, vitamins, also had moderate to good quantities of all the essential amino acids, the DM content of fresh
Potato veins was $11.9 \%$ and crude protein was $19.8 \%$ of DM (Kebede et al.,2008). Etela and Kalio (2011) reported that Potato veins could be used as an alternative supplementary feed for calves and small ruminants dry season and can be fed to dairy cattle as well (Ashiono et al.,2006). Due to the presence of anti-nutritional compounds such as trypsin inhibitor, hallucinogens, saponins, tannins, phytate and oxalate (Zhang and Corke, 2001) and (Aregheore, 2012), it can potentially be a negative effects on livestock production; which in turn its case reduction in palatability, digestibility, utilization of nutrients and rumen fermentation, resulting in not only decreased production but also low quality of meat and milk products (Alipour and Rouzbehan, 2007). Therefore, biotechnological processes, especially fermentation process may help in solving the antinutritional factors problems by hydrolysis of such antinutritional compounds which were reflected on its less effect on digestibility by animals (Pirmohammadi et al., 2012). Fermentation provides a good sanitary that does not contain Alfa-toxins, Salmonella, and Escherichia coli (Li et al., 2003).

The aims of this study were to investigate the effect of feeding fermented by-products mixture (some field and food industrial agricultural by products) completed replacement of clover hay on nutrient digestibility, nutritive values, milk yield and its composition, blood parameters and economic efficiency in the diets of dairy goats . 


\section{MATERIALS AND METHODS}

This work was conducted at Sakha Experimental Station, Animal Production Research Institute, (APRI), Agricultural Research Center, Egypt, in order to study the effects of total replacement of clover hay with two Fermented By-products Mixtures (FBM) which contain different proportion of field (Potato vines $\&$ rice straw) and food industrial agricultural (dried beet pulp \& molasses) by products in the diets of dairy goats on nutrient digestibility, nutritive values, milk production and composition, blood metabolites and economic efficiency.

\section{Fermented by-products mixture}

The fermented by-products mixtures (FBM) were prepared by using a potatoes vines, dried beet pulp, rice straw and molasses (with different percentages). Whereas, (FBM1) contained ( potatoes vines $65 \%$, rice straw $15 \%$, beet pulp $12 \%$ and molasses $8 \%$ ), meanwhile (FBM2) contain ( potatoes vines $74 \%$, rice straw $7 \%$, beet pulp $14 \%$ and molasses 5\%). Fermented By-products Mixtures, were made before two months of beginning of the experiment. Fresh potato vines wilted by spreading under the sun for one day, then chopped with rice straw and mixed with dried beet pulp and molasses and ensiled these mixture in plastic bags for 6 weeks. Representative samples were taken at the end of the period of ensiling for color, odor (as physical parameters) and fermentative analysis $(\mathrm{pH}$, Ammonia-Nitrogen and Total volatile fatty acids). Ammonia -nitrogen of the silage was determined according to A.O.A.C. (2007), whereas total volatile fatty acids (TVFA's) were determined by the steam distillation procedure of Warner (1964).

\section{Feeding and management}

The feeding experiment was conducted by using 18 Zaraibi lactating goats just after weaning at $13^{\text {th }}$ week. Goats at the $3^{\text {rd }}$ and $4^{\text {th }}$ parities and initial body weight mean was $40.5 \pm 1.5 \mathrm{~kg}$. The experimental animals were divided equally to three groups. The first group received concentrate feed mixture (CFM) and clover hay $(\mathrm{CH})$ as control diet (CD). Meanwhile, second and third groups received CFM and replacement $(\mathrm{CH})$ with (FBM1) as (TD1) group or with (FBM2) mixture as (TD2), group (on dry matter basis). The (CFM) amount fixed to provide animals with $40 \%$ of their requirement according to NRC (1986), while other ingredients (CH, FBM1 and FBM2) were added add-lib to animals to cover the rest $(60 \%)$ of their requirements. Feed offered and feeds refusals were weighted daily. Representative samples of each ingredients and mixtures were taken for chemical analysis. The feeding period lasted for 13 weeks. Daily feed intake was recorded for each group. Animals were weighed biweekly and changes in body weight were recorded.

Milk yield and milk sample

Milk yield was recorded weekly using milking hand technique, the total milk yield was calculated by summation of milk yield during all over the experimental period. Does were completely hand milked till stripping the udder one mutual meal (morning and evening) daily through two successive days through during milking period. Milk samples were analyzed for fat, protein, lactose and total solids by the automated infrared spectrophotometry (Foss 120 Milko-Scan, Foss Electric, Hillerød, Denmark) according to A.O.A.C. (1997) procedures. Solids-not-fat (SNF) was calculated (by differences). Fat corrected milk (FCM) for goats was calculated according to Mavrogenis and Papachristoforou (1988) equation, FCM for goat $=$ milk yield $(0.411$ $+0.147 * \%$ fat $)$.

Feed conversion was calculated as the amount of DM, TDN, ME and DCP units/ $1 \mathrm{~kg}$ fat corrected milk (FCM). At the end of this study, simple economical evaluation was calculated for tested diets according to the prevailing prices of ingredients during the time of experimental.

Where: prices as follows; concentrate feed mixture $=2200$ L.E.. ton, clover hay $=900$ L.E.. ton, potato vines silage $=95$ L.E. Iton, dried beet pulp $=1300$ L.E.Iton, rice straw $=280$ L.E.. ton, molasses $=950$ L.E. Iton, and price of $1 \mathrm{~kg} 4 \% \mathrm{FCM}=3.00$ L.E.

\section{Digestibility trials}

Digestibility trials lasted for 14 days was carried out on the dried animals after 2 weeks from last recording of milk production to determine nutrient digestibility of experimental diets using Acid Insoluble Ash (AIA) method which described by Van Keulen and Young (1977), through collected twice daily for 7 successive days. Representative samples of total mixed ration and feces, were analyzed according to A.O.A.O.(2007). The NDF and ADF were analyzed according to Van Soest's method (Van Soest et al., 1991). The metabolizable energy (ME) was calculated as 3.56Mcal / $1 \mathrm{~kg}$ TDN (McDonald et al., 1973).

\section{Blood samples}

Blood samples were taken from juggler vein at the end of the experimental. Samples were centrifuged at $3000 \mathrm{rpm}$ for $20 \mathrm{~min}$ to obtain blood serum. The supernatant was frozen and stored at $-20^{\circ} \mathrm{C}$ for subsequent analysis. Serum total protein assay was determined according to Gornal et al.(1949). Serum albumin was determined according to Doumas et al.(1971) and serum urea according Fawcett and Scott (1960). Serum Aspartate (AST) and alanine (ALT) aminotransaminases activities were determined according to Reitman et al.(1957). The serum globulin was calculated by the differences .

\section{Statistical analysis}

The data were analyzed using the general linear model procedure of SAS (1996). The differences among means were carried out according to Duncan's multiple range test (Duncan, 1955).

\section{RESULTS AND DISCUSSION}

Data of chemical composition of different ingredients and experimental diets are presented in Table (1). It is interested to note that the chemical composition of both fermented by-products mixture (FBM1 \& FBM2) is practically similar for all nutrients components. However, the $\mathrm{CD}$ (control) diet contained clover hay higher OM, $\mathrm{NDF}$ and ADF content, but lower ash content, when compared with other tested diets. 
Table 1. Chemical composition of different ingredients and experimental diets (on DM basis)

\begin{tabular}{|c|c|c|c|c|c|c|c|}
\hline \multirow{2}{*}{ Item } & \multicolumn{7}{|c|}{ Chemical composition \% (on DM basis) } \\
\hline & DM & OM & $\mathbf{C P}$ & NDF & ADF & $\mathbf{E E}$ & Ash \\
\hline \multicolumn{8}{|c|}{ Feed Ingredients } \\
\hline CFM & 90.65 & 91.44 & 16.57 & 25.63 & 21.84 & 3.74 & 8.56 \\
\hline $\mathrm{CH}$ & 87.82 & 90.33 & 11.31 & 50.42 & 38.36 & 1.84 & 9.67 \\
\hline PV & 21.64 & 83.28 & 14.74 & 54.42 & 37.62 & 1.93 & 16.72 \\
\hline $\mathrm{BB}$ & 89.13 & 95.37 & 11.82 & 41.32 & 32.81 & 0.86 & 4.63 \\
\hline RS & 90.12 & 88.57 & 3.87 & 71.25 & 54.38 & 1.43 & 11.43 \\
\hline M & 26.43 & 91.07 & 0.45 & - & - & 0.63 & 8.93 \\
\hline FBM1 & 41.7 & 90.5 & 12.45 & 55.4 & 44.7 & 2.5 & 9.5 \\
\hline FBM2 & 40.5 & 89.7 & 12.83 & 52.6 & 40.8 & 2.2 & 10.3 \\
\hline \multicolumn{8}{|c|}{ Experimental diets } \\
\hline $\mathrm{CD}$ & 100 & 89.47 & 14.13 & 42.37 & 24.18 & 2.08 & 10.53 \\
\hline TD1 & 100 & 87.84 & 14.42 & 41.68 & 23.73 & 2.16 & 12.16 \\
\hline TD2 & 100 & 87.28 & 14.55 & 41.32 & 22.86 & 2.24 & 12.72 \\
\hline
\end{tabular}

CFM=Concentrate Feed Mixtures; $\mathbf{C H}=$ Clover hay; $\mathrm{PV}=$ Potato veins; $\mathrm{BB}=$ Beat bulb; $\mathrm{M}=$ Molasses; $\mathrm{RS}=$ Rice straw.

FBM1 = first fermented by-products mixture FBM2= Second fermented by-products mixture

The FBM based silage contained on average 41,7 \& 40.5\%, dry matter (DM), $12.45 \& 12.83 \%$ crude protein (CP), $55.4 \& 52.6 \%$ neutral detergent fiber (NDF), $44.7 \& 40.80 \%$ acid detergent fiber (ADF), 2.5 \&2. $2 \%$ ether extract (EE), and ash content $9.5 \&$ $10.3 \%$ for (FBM1 \& FBM2), respectively. The variation in the chemical composition of experimental diets reflected the composition of their ingredients. The data indicated also, that the values of DM, CP, ADF,NDF, EE and Ash of Potato veins fall within the corresponding ranges reported by Mohamed et al. (2012). Meanwhile, the NDF and ADF contents ranged (41.32- 42.37\%) and (22.86 -24.18\%), respectively for tested diets. Whereas, NDF and ADF values with control diet, almost recorded higher values as compare with other experimental diets.

Fermented mixture quality

Physical and fermentation characteristics of fermented mixtures are presented in Table (2). The results showed that the two fermented mixtures were free from mold, caramelized with good smell and free from smells of tobacco or vinegar odor.

Table 2. Physical and fermentation characteristics of fermented mixtures.

\begin{tabular}{|c|c|c|c|c|c|c|}
\hline Items & 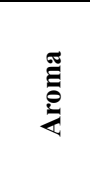 & 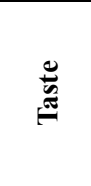 & 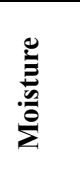 & pH & 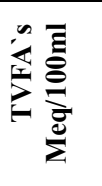 & 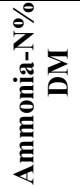 \\
\hline FBM1 & Good & Good & $40 \%$ & 4.10 & 15.82 & 0.20 \\
\hline FBM2 & Good & Good & $39 \%$ & 4.32 & 16.28 & 0.15 \\
\hline
\end{tabular}

Results in Table (2) showed that overall mean of $\mathrm{pH}$ values of the two fermented mixtures appeared to be within the normal range given by Abou-Akkada and Nour (1986) being (4.10 to 4.32). Results in Table (2) indicated the overall mean of TVFA's concentration recorded 15.82 and $16.28 \mathrm{Meq} / 100 \mathrm{ml}$. for FBM1 \& FBM2, respectively, showing somewhat higher concentration with $2^{\text {nd }}$ one than the first. There were no clear differences between two fermented by-products mixtures in concentration of ammonia-N\%. The physical and fermentative characteristics of agricultural fermented by-products mixture (Table 2) indicated that the two fermented mixtures showed good characteristics as proposed by both Nishino et al.(2007) and Wang and Nishino (2008). However, fermentation characteristics are in agreement with previous studies reported by Wang et al.(2011).

Nutrient digestibility coefficients and nutritive values Results of nutrients digestibility and nutritive values of experimental diets are presented in Table (3). The data in Table (3) showed that the fermented byproducts mixtures (TD1\&TD2) diets showed higher digestibility coefficients of DM, OM, CP, NDF and ADF than control diet. On the meantime, there were no significant differences among experimental diets for EE digestibility, as a result of increasing ruminal fermentation with fermented mixtures (TD1\&TD2). The superiority of NDF and ADF digestibility of (TD1\&TD2) could be due to feeding fermented mixtures which enhanced cellulolytic bacteria activity accordingly more NDF and ADF were digested.

Table 3. Digestibility coefficients and nutritive values of experimental diets.

\begin{tabular}{lcccl}
\hline Item & \multicolumn{2}{l}{ Experimental Diets } & \multirow{2}{*}{ tSE } \\
& CD & TD1 & TD2 & \\
\hline Digestibility coefficients, \% & & & \\
DM & $61.78^{\mathrm{b}}$ & $62.54^{\mathrm{ab}}$ & $64.62^{\mathrm{a}}$ & 0.61 \\
OM & $63.67^{\mathrm{b}}$ & $64.72^{\mathrm{ab}}$ & $66.48^{\mathrm{a}}$ & 0.67 \\
CP & $65.82^{\mathrm{b}}$ & $68.54^{\mathrm{a}}$ & $69.42^{\mathrm{a}}$ & 0.78 \\
NDF & $55.64^{\mathrm{b}}$ & $59.73^{\mathrm{a}}$ & $60.21^{\mathrm{a}}$ & 0.64 \\
ADF & $51.82^{\mathrm{b}}$ & $54.68^{\mathrm{a}}$ & $56.84^{\mathrm{a}}$ & 0.65 \\
NFE & $72.63^{\mathrm{b}}$ & $74.38^{\mathrm{ab}}$ & $74.88^{\mathrm{a}}$ & 0.52 \\
EE & 77.36 & $77.72^{2}$ & 77.54 & 0.46 \\
Nutritive value, & $\%$ & & & \\
TDN & $59.91^{\mathrm{b}}$ & $63.74^{\mathrm{ab}}$ & $64.9^{\mathrm{a}}$ & 1.64 \\
DCP & $9.30^{\mathrm{b}}$ & $9.88^{\mathrm{a}}$ & $10.10^{\mathrm{a}}$ & 0.87 \\
ME (Mcal/kg) & $2.45^{\mathrm{c}}$ & $2.77^{\mathrm{b}}$ & $2.89^{\mathrm{a}}$ & 0.42 \\
\hline
\end{tabular}

a,b and $c$ Means in the same raw with different superscripts differ $(\mathbf{P}<\mathbf{0 . 0 5})$

The observed improvement in nutrients digestibilities with TD1 and TD2 diets compared to the control diet (CD), may be attributed to the ensiling mixture which enhanced micro flora activity accorded to digest NDF and ADF much better $(\mathrm{P}<0.05)$ than control diet $(\mathrm{CD})$. The data pointed out that there was 
no significant differences in digestibility of DM, OM, CP NDF and ADF between diets TD1 and TD2. It is observed that the TD2 diet had the highest DM, OM , $\mathrm{CP}, \mathrm{NDF}$ and ADF digestibility than the other two diets.

The effect of fermented feeds on digestibility may be a consequence of improved nutrient preservation during the fermentation process and conservation of greater proportion of digestibility nutrients Yang et al. (2009). These results were agreement with both Mohamed et al.(2012) and Kim et al. (2014) who reported that the including of fermented feeds in ruminant rations increased nutrients digestibility coefficients. Results obtained in this study revealed that the fermented mixture increase NDF and ADF digestibility with TD1 \& TD2 diets. Huisden and McAllister (2009) and Makoto et al. (2014) reported that higher ruminal degradability of DM and fermented feed reduced ruminal $\mathrm{pH}$ and sugar concentration, enhancing lactic acid production, which facilitates DM disappearance with calves .

The TD2 diet had the highest values of nutritive values as TDN, DCP and ME (Mcal $/ \mathrm{kg})$, while diet of $\mathrm{CD}$ showed the lowest one. This may be possibly as a result to attribute the improvement of nutrients digestibility coefficients of rations containing fermented by-products mixtures. These results are in good agreement with those obtained by Wang et al.(2011); Mohamed et al. (2012) and Kim et al. (2014) who compared between animals received ration including fermented mixture and other group fed ration without fermented mixture. They obtained significant higher nutritive value expressed as TDN value of the rations including fermented by-products mixtures than the group was not fed fermented mixture.

\section{Milk yield and its composition}

Data of average daily milk yield (ADMY) and its milk composition are presented in Table (4). The differences in milk yield and fat corrected milk (FCM) were significant $(\mathrm{P}<0.05)$ among the tested experimental diets. The (ADMY) had the highest values with TD2 (1.25 kg/head), Meanwhile, the lowest value was recorded with $\mathrm{CD}(0.95 \mathrm{~kg} / \mathrm{head}) . \mathrm{In}$ this respect, values of $(\mathrm{FCM})$ were taken the same trend as that of average daily milk yield. The highest $(\mathrm{P}<0.05)$ values with TD2 (1.13 kg/head), Meanwhile, the lowest value was recorded with $\mathrm{CD}(0.87 \mathrm{~kg} / \mathrm{head})$ group. On the meantime, there were no significant differences between TD1\& TD2 for milk yield and (FCM). Improving of the digestion coefficients of most nutrients and feeding values improving with tested diets was reflected on more milk yield produced by does fed such diets (TD1\&TD2). The obtained results indicated the positive effect of tested diets TD1\&TD2 over that of the control diet. The obtained values are in agreement with those reported by Mohamed et al. (2012) and Khan et al. (2015) who illustrated that inclusion silage in dairy animals ration resulted in increasing milk yield, these may be due to one or more of the following reasons, 1) higher DMI and higher nutrients digestibility and 2) increased rumen micro flora activity which lead to an improve of feed efficiency hence an increase milk production.

Table 4. Effect of feeding experimental diets on milk yield and its composition (during total period, 13 week).

\begin{tabular}{|c|c|c|c|c|}
\hline & \multicolumn{3}{|c|}{ Experimental Diets } & \multirow{2}{*}{$\pm \mathrm{SE}$} \\
\hline & CD & TD1 & TD2 & \\
\hline \multicolumn{5}{|l|}{ Milk yield, kg /head/day } \\
\hline $\begin{array}{l}\text { Av.daily milk yield,kg } \\
\text { /h/d }\end{array}$ & $0.95^{\mathrm{b}}$ & $1.16^{\mathrm{a}}$ & $1.25^{\mathrm{a}}$ & 0.28 \\
\hline $\begin{array}{l}\text { Av. fat corrected milk, } \\
\mathrm{kg} / \mathrm{h} / \mathrm{d}\end{array}$ & $0.87^{\mathrm{b}}$ & 1.05 & $1.13^{\mathrm{a}}$ & 0.4 \\
\hline \multicolumn{5}{|l|}{ Milk composition ,\% } \\
\hline Fat, $\%$ & 3 & 3. & 3. & 0.19 \\
\hline Av. Fat & & & & 2 \\
\hline Protein & 3 & 3. & & 0.21 \\
\hline Av. Prot & $35.2^{\mathrm{b}}$ & $42.2^{\mathrm{a}}$ & $44.7^{\mathrm{a}}$ & 0.34 \\
\hline Lac & & 4. & 4. & 0.15 \\
\hline Av. La & $40.3^{\mathrm{b}}$ & 49 & $53.3^{\mathrm{a}}$ & 0.36 \\
\hline Total sol & 11.40 & 11.29 & 11.21 & 0.31 \\
\hline $\begin{array}{l}\text { Av. Total solids yield, } \\
\mathrm{g} / \mathrm{h} / \mathrm{d}\end{array}$ & , $108^{\mathrm{c}}$ & 13 & $140^{\mathrm{a}}$ & 0 \\
\hline Solids not fat, $\%$ & 7.94 & 7.89 & 7.85 & 0.16 \\
\hline $\begin{array}{l}\text { Av.Solids not fat yield, } \\
\mathrm{g} / \mathrm{h} / \mathrm{d}\end{array}$ & $75.4^{\mathrm{c}}$ & 91. & $98.1^{\mathrm{a}}$ & 0.46 \\
\hline Ash, $\%$ & 0.8 & & & \\
\hline Av. Ash yield, g/h/d & 8.26 & 9.86 & 11.1 & 0.29 \\
\hline
\end{tabular}

a,b and $\mathrm{c}$ Means in the same raw with different superscripts differ $(\mathbf{P}<0.05)$.

Fat correct milk (4\%) for goats calculated according to the following equation : FCM $\mathrm{kg}=$ milk yield $(0.411+0.147 * \% f)$.

In spite the observed insignificant effect of experimental diets on milk components, there was a tendency of increase in milk components yield of does fed diet containing (TD1\&TD2). In agreement with present results, Sommart et al. (2000), Chen et al. (2004), Mohamed et al. (2012), Khalid et al. (2013) and Saleh (2014) found that including fermented mixture increased components milk yield, but did not have a significant effect on milk composition (fat, protein, lactose and total solids) among experimental diets during milking period. These improvement in both milk yield and milk components yield in (TD1\&TD2) was correlated with the high $\mathrm{OM}, \mathrm{CP}, \mathrm{NDF}, \mathrm{ADF}$ and NFE digestibility. Results obtained in present study are in harmony with those found by Mohamed et al. (2012) and Huhtanen et al. (2013) who speculated positive effect of inclusion fermented by-products mixtures in dairy rations in comparison of the traditional ration.

\section{Blood parameters}

Values of some blood serum parameters are presented in Table (5). Diets containing fermented byproducts mixture (TD1\&TD2) was tended to increase significantly $(\mathrm{P}<0.05)$ for total protein, albumin, $\mathrm{A} / \mathrm{G}$ ratio and glucose concentrations compared with control diet. While, increasing in globulin was not significant among diets.

Data in Table (5) showed that the highest mean values of serum total protein Albumin and $\mathrm{A} / \mathrm{G}$ ratio were recorded with (TD2) group. These results may be due to the improvement in nutrients digestibility 
(protein \& energy). Singh et al. (2013) reported that dietary protein and energy levels are the most effective factors in blood picture. Serum total protein and its fractions are considered as a biological index reflecting health and performance of animal (Singh and Jha, 2009). These results were agreement with the conclusion of Kumar and Vaithiyanathan (1990) and Singh et al. (2013) who reported positive correlation between dietary protein and serum protein concentration. Gang et al. (2014) noticed that the increase in digestibility of CP may be the reason for the increase in each of serum total protein and albumin concentration. Also, these results could probably attributed to the higher of glucose and protein concentration in blood serum of TD1\&TD2 in (Table 5). It led to an increase in milk lactose synthesis and consequently milk production being increased. Also, the increasing in milk protein yield in the current study may be due to the more energy being available or milk protein synthesis, these finding agreed with Kuoppala et al. (2008) and Mohamed et al. (2012). Values of serum protein fraction indicated better utilization of dietary protein which led to better rumen microbial capture of forage nitrogen and ruminal nitrogen through digestive tract as result in lower ruminal ammonia-N production (Winters et al., 2001; Davies et al., 2012 and Gang et al., 2014).

Table 5. Blood serum parameters as affected by feeding experimental diets.

\begin{tabular}{|c|c|c|c|c|}
\hline \multirow[b]{2}{*}{ Item } & \multicolumn{3}{|c|}{ Experimental Diets } & \multirow{2}{*}{$\pm \mathrm{SE}$} \\
\hline & CD & TD1 & TD2 & \\
\hline $\begin{array}{l}\text { Total protein } \\
(\mathrm{mg} / \mathrm{dI})\end{array}$ & $8.02^{\mathrm{b}}$ & $8.43^{\mathrm{a}}$ & $8.49^{\mathrm{a}}$ & 0.12 \\
\hline Albumin $(\mathrm{mg} / \mathrm{dI})$ & $3.95^{\mathrm{b}}$ & $4.33^{\mathrm{a}}$ & $4.38^{\mathrm{a}}$ & 0.08 \\
\hline Globulin(mg/dI) & 4.07 & 4.10 & 4.11 & 0.21 \\
\hline A/G Ratio & $0.97^{\mathrm{b}}$ & $1.06^{\mathrm{a}}$ & $1.07^{\mathrm{a}}$ & 0.16 \\
\hline Glucose $(\mathrm{mg} / \mathrm{dI})$ & $37.44^{b}$ & $39.73^{\mathrm{a}}$ & $41.80^{\mathrm{a}}$ & 0.41 \\
\hline AST $(\mathrm{U} / 100 \mathrm{ml})$ & 60.43 & 61.28 & 61.65 & 0.48 \\
\hline $\operatorname{ALT}(\mathrm{U} / 100 \mathrm{ml})$ & 28.63 & 28.68 & 28.65 & 0.28 \\
\hline
\end{tabular}

Blood serum Aspartate - amino transferase (AST) and Alanine - amino transferase (ALT) values were not significantly affected by experimental rations. Data indicated healthy status of the liver since the liver is the main organ of albumin synthesis. The present values of AST and ALT showed normal activity of the animal hepatic tissue and consequently, the integration of fermented by-products in the present investigation could be used without any adverse effect on the liver functions. In general, the obtained concentrations of blood constituents are within the normal range for healthy goats which reported by (Gihad et al., 1987 and Kim et al., 2012). So, there weren't any worst effect on lactating goats health when fed on fermented byproducts on a long run in their rations.

\section{Feed conversion and economic efficiency of} experimental diets

The results of nutrients intake, feed conversion for milk production and economic efficiency of the experimental diets are presented in Table (6). Total nutrients intake / head as DM, TDN, ME and DCP by lactating does for (TD1\&TD2) were higher as compared with control diet (CD). These results could probably attributed to the higher of the digestion coefficients of most of the nutrients and the feeding values of TD1\&TD2 in (Table 3). Improving of TD1\&TD2 was reflected on more milk yield produced by does fed such diets. These results had correlation effect with data of milk yield, feed intake and feeding values of TD1\&TD2. This result agree with result showed by Bunyeth and Preston (2005) and Ashiono et al. (2006) and Khalid et al. (2013). Including (FBM) in tested diets improved the feed conversion values in terms of $\mathrm{kg}$ TDN, ME and DCP / $1 \mathrm{~kg}$ FCM as compared with control diet. As for the results of feed conversion, it was improved by does fed TD2 diet since it had the best value of feed conversion, followed by TD1, while CD recorded the lowest value calculated as TDN, ME and DCP / $1 \mathrm{~kg}$ FCM. Replace clover hay with FBM resulted in better feed conversion values (1.35\& 1.28), (857\& $832),(3.74 \& 3.71)$ and $(133 \& 129)$ for DMI, TDN, ME and DCP with (TD1\&TD2), respectively for producing $1 \mathrm{~kg}$ FCM compared to control diet.

Table 6. Effect of the experimental diets on feed intake, feed conversion and economic efficiency (during total period, 13 week).

\begin{tabular}{|c|c|c|c|}
\hline \multirow{2}{*}{ Item } & \multicolumn{3}{|c|}{ Experimental Diets } \\
\hline & & TD1 & TD2 \\
\hline \multicolumn{4}{|l|}{ Nutrients Intake } \\
\hline Total DM intake, $\mathrm{kg} /$ head & 1.34 & 1.42 & 1.45 \\
\hline Total TDN intake, $\mathrm{kg} /$ head & 0.80 & 0.90 & 0.94 \\
\hline Total ME intake, Mcal / head & 3.28 & 3.93 & 4.19 \\
\hline Total DCP intake, $\mathrm{g}$ / head & 125 & 140 & 146 \\
\hline Av.fat corrected milk,kg/head/d & 0.87 & 1.05 & 1.13 \\
\hline \multicolumn{4}{|l|}{ Feed Conversion } \\
\hline Av. DM, $\mathrm{kg} / \mathrm{kg}$ milk & 1.54 & 1.35 & 1.28 \\
\hline Av. TDN, g/ kg milk & 919 & 857 & 832 \\
\hline Av. ME, Mcal / kg milk & 3.77 & 3.74 & 3.71 \\
\hline Av. DCP, g/ kg milk & 144 & 133 & 129 \\
\hline \multicolumn{4}{|l|}{ Economic Efficiency } \\
\hline Av.daily feed, cost/ head/d L.E. & 2.37 & 2.16 & 2.12 \\
\hline $\begin{array}{l}\text { Total cost of feed } / \text { head } \\
\text { L.E.(13week) }\end{array}$ & 213.5 & 194.4 & 191.3 \\
\hline Total Price, milk L. E./ head & 234.9 & 283.5 & 302.3 \\
\hline Net revenue ${ }^{\mathrm{A}}$, L.E./ head & 21.4 & 89.3 & 111 \\
\hline Economic Efficiency ${ }^{B}$ & 1.10 & 1.46 & 1.58 \\
\hline Economic Efficiency Improvement, $\%$ & . & 32.7 & 43.6 \\
\hline
\end{tabular}

A- Net revenue $(\mathrm{LE} /$ goat/day $)=$ money output - money input

\section{B- Economical efficiency $=$ money output $/$ money in put}

These results are in agreement with results of Mohamed et al. (2012) and Khan et al. (2015) found that improvement in feed conversion as DMI and $\mathrm{CPI} / \mathrm{milk}$ yield reached to about 8.5 and $11.3 \%$, respectively compared to control. The positive effect of feed conversion efficiency was observed also by Mohamed et al. (2012); Khalid et al. (2013); Saleh (2014) and Khan et al. (2015) with including (FBM) in tested diets improved the feed conversion in small ruminant rations. 
It is of interest to observe that daily feed cost /head/day was more pronounced with the $\mathrm{CD}$; meanwhile, the TD2 showed the lowest daily feed cost /head/day. The average daily feed cost decreased by 8.8 and $10.5 \%$ with (TD1\&TD2), respectively as compared to control diet. The net revenue (profit) above feeding cost (Table 6) was higher with TD1\&TD2 diets including fermented by-products mixtures (FBM) than the control diet. The economic efficiency was improved by 32.7 and $43.6 \%$ with (TD1\&TD2), respectively as compared to control diet. On the meantime, values of the economic efficiency are given in Table (6) illustrated that the FBM replacement in (TD1\&TD2) reflected superiority over the control diet. The improvement of economic efficiency for (TD1\&TD2) could be related to the high feed conversion efficiency, as well as to the positive effect of Including (FBM) on the nutritive value Giang et al., (2004); Bunyeth and Preston (2005) and Ashiono et al. (2006) of tested diets not only that but to the less concentration of antinutritional compounds (Pirmohammadi et al., 2012). The current study confirmed that, there is a positive relation between fermented by-products mixture and economic efficiency pathway decreased feeding cost and increasing milk yield produced by does fed such diets. These results are confirmed by Saleh (2014) and Khan et al. (2015) who reported that utilization of fermented by-products mixture support the farmer's income through produce more milk per animal. In addition, Mohamed et al. (2012) and Khalid et al. (2013) found that the diets containing fermented byproducts mixture could be economically and successfully be used for lactating animals to improve economic efficiency increasing net revenue (profit) .

\section{CONCLUSTION}

From the results obtained in this study it could be concluded that fermented by-products mixtures (FBM1\&FBM2) fed successfully and economically as full replacement for clover hay for lactating does without any adverse effects on animal performance which reflected on feeding cost and economic efficiency. Further studies are needed on commercial scale for better utilization with available different agricultural by-products which will be reflected in the improvement of livestock holder income in Egypt.

\section{REFERENCES}

A.O.A.C.(1997). Official Methods of Analysis AOAC Int., Gaithersburg, MD.

A.O.A.C.(2007). Official Methods of Analysis of AOAC International, 16th ed. Agricultural, Chemicals, Contaminates, Drugs, vol. 1. Washington, D. C, USA.

Abou Akkada, A. R. and A.M. Nour (1986). Ensilage and improvement of feeding value. Alexandria, September, p: 40-52.

Agricultural Economics-Ministry of Agriculture in Egypt (2014). Central Administration, Agricultural Economics, Yield and Production of different crops. Economics Affairs Sector, Ministry of Agriculture in Egypt.
Alipour, D. and Y. Rouzbehan (2007). Effects of ensiling grape pomace and addition of polyethylene glycol on in vitro gas production and microbial biomass yield. Animal Feed Science and Technology 137: 138-149. Analytical Chemists; Washington, DC, USA.

Aregheore, E.M. (2012). Nutritive value and inherent antinutritive factors in four indigenous edible leafy vegetables in human nutrition in Nigeria: A review. Journal of Food Resource Science 1.1: 114.

Ashiono, G. B.; J.O. Ouda; T.E. Akuja; J. K. Kitilit; R.G. Irungu and S. Gatwiku (2006). Effect of potato vine and sorghum silage on cattle milk productivity. Asian Journal of Plant Sciences 5 (1) 81-84.

Bunyeth, H. and T.R. Preston (2005). The effect of ensiling or sun-drying cassava leaves on feed intake, digestibility and $\mathrm{N}$ retention of goats fed a basal diet of para grass (Brachiaria mutica). Asian Journal of Plant Sciences 7 (2) 52-64.

Chen, D.; O.Eulenstein and D.Fernández-Baca (2004). Rainbow: A toolbox for phylogenetic supertree construction and analysis. Bioinformatics, 20(16):2872-2873.

Davies, D.R.; P. Nunn; J. Hildon and J. Cook (2012). The effect of feeding grass silage inoculated with Power start on dairy herd fertility. XVI International Silage Conference Finland: 478479.

Doumas, B.; W. Waston and H. Biggs (1971). Albumin standards and measurements of serum with bromocresol green. Clin. Chem. Acta, 31: 87-94.

Duncan, D.B.(1955).Multiple ranges and multiple "F" test Biometrics, 11:1-42.

Etela, I. and G.A. Kalio (2011). Yields components and 48$\mathrm{h}$ rumen dry matter degradation of three sweet potato varieties in N'dama steers as influenced by date of harvesting. Journal of Agriculture and Social Research 11.2: 15-21.

F.A.O. (2008). Economic and Social Dep. Global perspective Agriculture, Towards 2015/30. Technical Interim Report. Food and Agric. Org of the UN., Rome Italy.

Fawcett, J. K. and J.E. Scott (1960). A rapid and precise method for the determination of urea . J. Clin. Path., 13:156-159.

Gang, G. ; S. J. Ohh; B. J. Hong and J. S. Shin (2014). Changes in serum metabolites and growth characteristics of Korean native steers fed alcohol-fermented feeds. Asian-Aust. J. Anim. Sci. 17:648-654.

Giang, H.H.; L.V. Ly; B. Ogle Brian ( 2004). Digestibility of dried and ensiled sweet potato roots and vines and their effect on the performance and economic efficiency of F1 crossbred fattening pigs. Agricultural and Food Science 21: 32-46.

Gihad, E.A.; T. I. El-Gallad; S.M. Allam and T. M. ElBedway (1987). Effect of pre and post - partum nutrition on birth and early milk yield in goats. Vol (2) 4th Int. Conf. on goats, 8-13 March, Brasilia, Abstract, pp. 1401-1412. 
Gornal, A.G;C.J. Bardawill and M.M. David (1949). Determination of serum proteins by Means of biuret reaction. J. Biol. Chem., 177:151-159.

Huhtanen, P.; S. Jaakkola and J. Nousiainen (2013). An overview of silage research in Finland: from ensiling innovation to advances in dairy cow feeding. Agricultural and Food Science 22: 35-56.

Huisden, L.N. and T.A. McAllister (2009). Effect of inoculants on whole-crop barley silage fermentation and dry matter disappearance in situ. J Anim Sci. 2009 Feb;80(2):510-516.

Kebede, T.; T. Lemma; E. Tadesse and M. Guru (2008). Effect of level substitution of sweet potato vines for concentrate on body weight gain and carcass characteristics of browsing Arsi Bale.Journal of Cell and Animal Biology 2.2: 36-42.

Khalid, A. F.; K. M. Elamin; A. E. Amin; A. A. Tameem Eldar; M. E. Mohamed; H. E. Hassan and M. D. Mohammed (2013). Effect of feeding sweet Potato (Ipomoea batatas) vines silage on performance and milk production of Nubian goats J. Vet. Adv., 3(5): 153-159

Khan, N. A.; Yu, P.; Ali, M.; Cone, J. W. and W. H. Hendriks (2015). Nutritive value of maize silage in relation to dairy cow performance and milk quality. Journal of the Science of Food and Agriculture 95.2: 238-252.

Kim, Y. I. ; Y. K. Oh; K. K. Park, and W. S. Kwak (2014). Ensiling Characteristics and the In situ Nutrient Degradability of a By-product Feedbased Silage. Asian-Australasian Journal of Animal Sciences (AJAS); 27(2): 201-208.

Kim, S.H.; Gu, M.J.; Park, K.W.; Jeon, C.O.; Ha, Jong K.; Cho, K.K. and Lee, S.S. (2012). Effect of total mixed ration with fermented feed on ruminal in vitro fermentation, growth performance and blood characteristics of Hanwoo steers. AsianAustralasian Journal of Animal Sciences (AJAS); 27(2): 115-122.

Kumar, R. and S. Vaithiyanathan (1990). Occurrence, nutritional significance and effect on animal productivity of tannins in tree leaves. Anim. Feed Sci. Tech. 30:21-38.

Kuoppala, K.; M. Rinne; J. Nousiainen and P. Huhtanen (2008). The effect of timing of grass silage harvest in primary growth and regrowth and the interactions between silage quality and concentrate level on milk production of dairy cows. Livestock Science 116: 171-182.

Li， D.Y.; J.Y.Ko; N.J. Choi;S.S.Lee; J.Y. Song; S.Y. Lee;S.H. Park;H.G. Sung and J.K. Ha (2003). Effects of types of TMR on rumen fermentation characteristics and nutrients digestibility in sheep. J. Anim. Sci. Technol. 45:805-812.

Makoto, K. ;Y. Hirano; K. Kita; A. Jayanegara and H. Yokota (2014). Fermentation Characterize Mastics, Tannin Contents and In vitro Ruminal Degradation of Green Tea and Black Tea Byproducts Ensiled at Different Temperatures. Asian-Australasian Journal of Animal Sciences (AJAS); 27(7): 937-945.
Mavrogenis, A.P. and C.H.R. Papachristoforou (1988) . Estimation of the Energy Value of Milk and Prediction of Fat-Corrected Milk Yield in Sheep and Goats. Small Ruminant Research, 1 (1988) 229-236 229 Elsevier Science Publishers B.V., Amsterdam -- Printed in The Netherlands

McDonald, P.; R.A. Edwareds and J. F. D. Green Haigh (1973). Animal Nutrition. Six addition pub. ISBN (Longman Scientific and Technical).

Mohamed, A.H.; Amany A. Khayyal; M.H. Abo El-Fadel; A.M. Hussein and T. Ashmaoy (2012). Influence of including some vegetables by-products silage in ewes rations on digestibility and productive performance. The 13th Scientific Conference of Animal Nutrition,14-17 February Sharm $\mathrm{El}=$ Sheikh City, Egypt. Issued by Egyptian Journal of Nutrition and Feeds.

N.R.C.(1986). Nutrients requirements of goats in temperate and tropical countries. National Academy of Press, Washington D.C., USA.

Nishino, N. ; T. Kawai, and M. Kondo ( 2007). Changes during ensilage in fermentation products, tea catechins, antioxidative activity and in vitro gas production of green tea waste stored with or without dried beet pulp. J Sci Food Agric. 87:1639-1644.

Pirmohammadi, R. ; O. Hamidi, A; Golgasemgarebagh and S. Cheraghiyan (2012). Effect of polyethylene glycol-6000 on chemical composition and degradability of white grape pomace in buffaloes. Journal of Animal and Plant Sciences 22.Suppl 3: 270-272.

Reitman, S. and S. Frankel (1957). Calorimetric method for the determination of serum Alanine transferees and Aspartate transferees. Am. J. Clin. Path., 28:56.

ruminal productivity of tennis in tree leaves. Animal feed Science and Technology. 30:21-32.

S.A.S.( 1996). Statistical analysis system. User,s guide, version 6, 4th ed., Vol. 2,Cary NC:SAS Institute (INC).

Saleh, M.R.M. (2014). Effect of natural total glycolalkaloids in discarded potato tubers and vines on milk yield and rumen environmental in dairy goats. J. Animal and Poultry Prod., Mansoura Univ., Vol. 5(12):737-757.

Singh, V.K.; A.K. Pattanaik; T.K. Goswami and K. Sharma (2013). Effect of varying the energy density of protein-adequate diets on nutrient metabolism, clinical chemistry, immune response and growth of Muzaffarnagari lambs. Asian-Australasian Journal of Animal Sciences 26.8: 1089-1101.

Singh, A. and S.K. Jha (2009). Developments in Technology for Fodder Densification. In Walli K.,ed. Proceedings of the national symposium on fodder block technology, pp. 93-98.

Slovak Journal of Animal Science 47.2 (2014): 90-99. 
Sommart, K. ; M. Wanapat; P. Rowlinson; DS.Parker; P. Climee and S. Panishying (2000). The use of cassava chips as an energy source for lactating dairy cows fed with rice straw .Asian Journal Animal Science 13(8) 1094-1101.

Van Keulen, J. and B. A. Young (1977). Evaluation of acid insoluble ash as a nature marker in ruminant digestibility studies. J. Anim. Sci., 44:282- 287.

Van Soest, P. J. ; J. B. Ro/bertson, and B. A. Lewis (1991). Methods for dietary fiber, neutral detergent fiber and non-starch polysaccharides in relation to animal nutrition. J. Dairy Sci. 74:3583-3597.

Wang, R.R. ; H.L. Wang; X. Liu and CC. Xu (2011). Effects of different additives on fermentation characteristics and protein degradation of green tea grounds silage. Asian Australas J Anim Sci.24:616-622.

Wang, F. and N. Nishino (2008). Ensiling of soybean curd residue and wet brewers grains with or without others feeds as a total mixed ration. J. Dairy Sci., 91, pp.2380 - 2387.
Warner, A.C.I. (1964). Production of volatile fatty acids in the rumen. Methods of measurement. Nutr. Abstr. And Rev., 34:339-345.

Winters, A.L.; R. Fychan and R. Jones (2001). Effect of formic acid and bacterial inoculant on the amino acid composition of grass silage and on animal performance. Grass and Forage Science 56: 181192.

Yang, C.; T.Takahashi and K. Horiguchi (2009). Effects of addition of food by-products on the fermentation quality of a total mixed ration with whole crop rice and its digestibility, preference, and rumen fermentation in sheep. Animal Feed Science and Technology Volume 15(1) 1-2.

Zhang, Z. and H. Corke (2001). Trypsin inhibitor activity in vegetative tissue of sweet potato plants and its response to heat treatment. Journal of the Science of Food and Agriculture 81: 1358-1363.

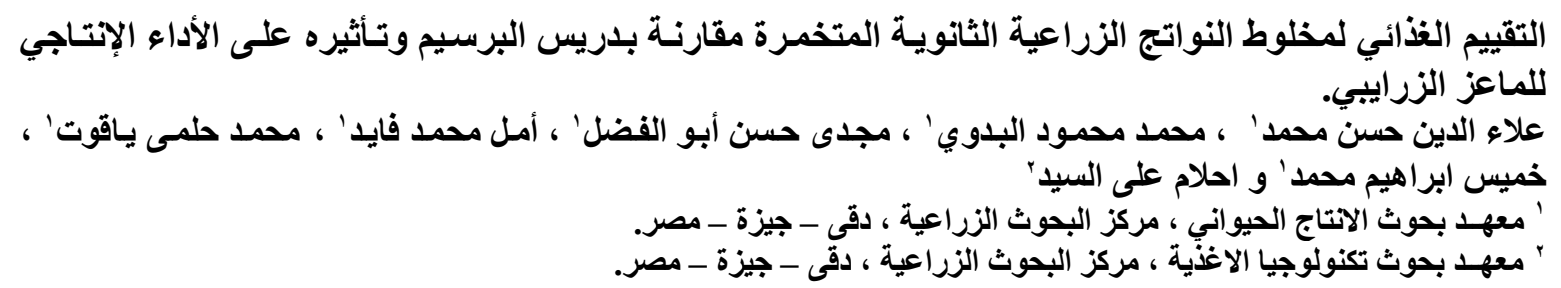

تهدف هذه الدر اسـة الى تقيهم خصائص مخلوط المخلفـات الزر اعيـة ( الحقلية ومخلفـات التصنيع الزراعي) المتخمـر

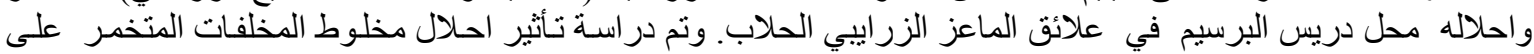

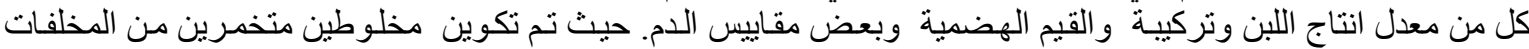

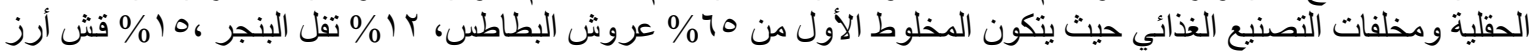

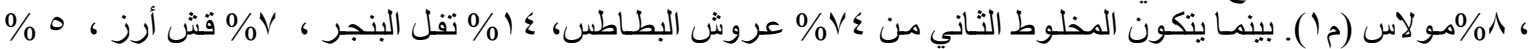

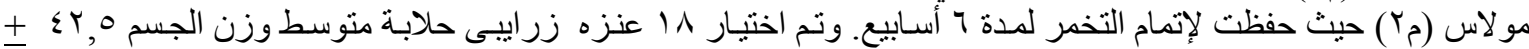

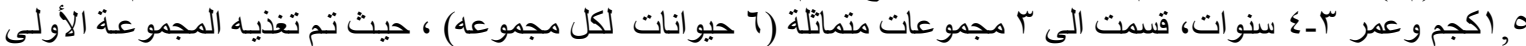

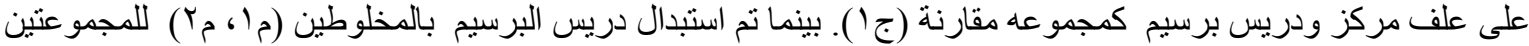

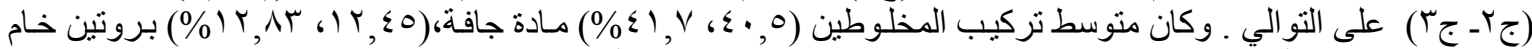

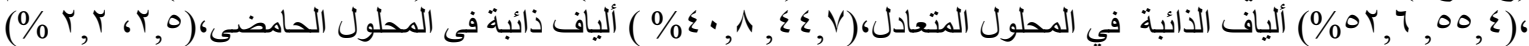

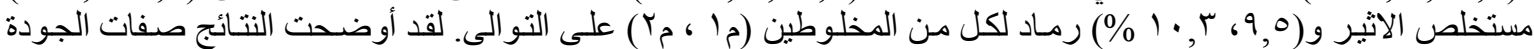

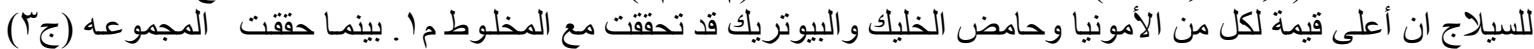

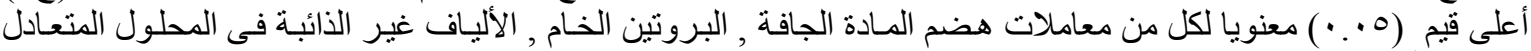

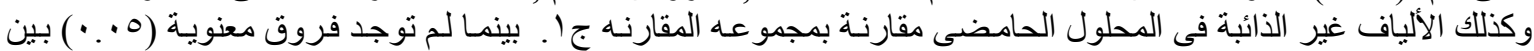

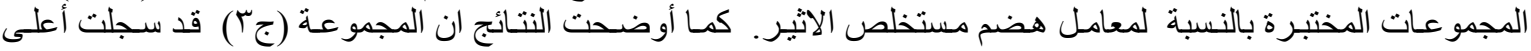

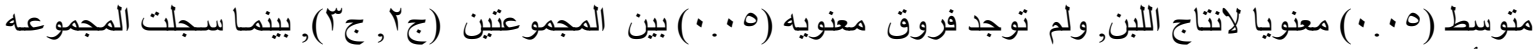

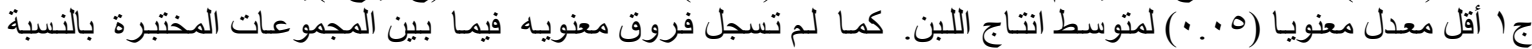

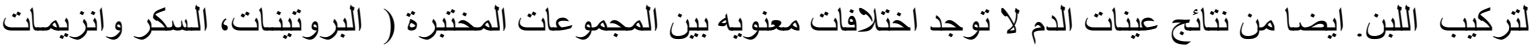

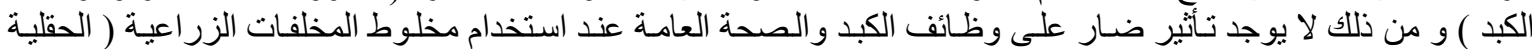

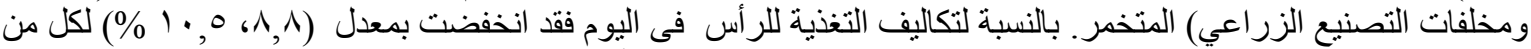

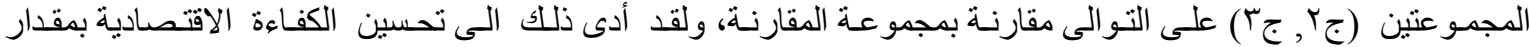

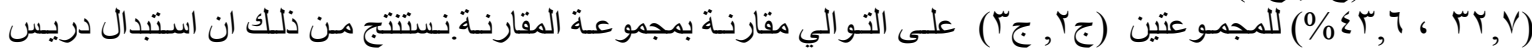

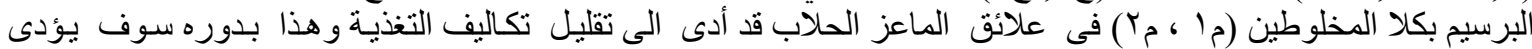
الى تو افر مصادر علفية جديدة غير تقليدية تسهم فى حل جزء من الفجوة العلفية فى مصر مما يؤدى الى تقليل تكاليف الانتاج . 